Archived version from NCDOCKS Institutional Repository http://libres.uncg.edu/ir/asu/

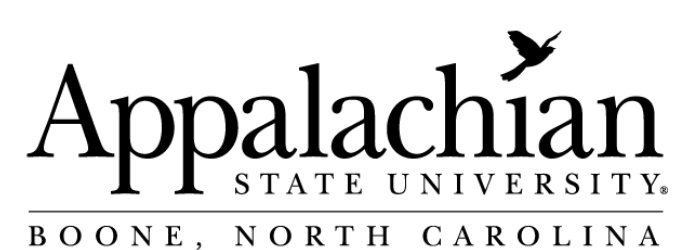

\title{
Change Drivers In The New Millennium: Implications For Manufacturing Strategy Research
}

\author{
By: Caron H. St. John, Alan R. Cannon, and Richard W. Pouder
}

\begin{abstract}
Drawing on multiple sources, we identify technological, global and workforce trends that will affect the formulation and implementation of manufacturing strategy in the next decade. We then describe several theories from economics, sociology, and psychology and show how they can be used to enrich our interpretations of the effects of these trends. Throughout, we offer suggestions for future research in manufacturing strategy.
\end{abstract}

St. John, C. H., et al. (2001). "Change drivers in the new millennium: implications for manufacturing strategy research." Journal of Operations Management 19(2): 143-160. https://doi.org/10.1016/S0272-6963(00)00054-1. Publisher version of record available at: https://www.sciencedirect.com/science/article/pii/S0272696300000541 


\title{
Change drivers in the new millennium: implications for manufacturing strategy research
}

\author{
Caron H. St. Johnn ${ }^{\mathrm{a}, *}$, Alan R. Cannon ${ }^{\mathrm{b}, 1}$, Richard W. Pouder ${ }^{\mathrm{c}, 2}$ \\ a Department of Management, Clemson University, 101 Sirrine Hall, P.O. Box 341305, Clemson, SC 29634-1305, USA \\ ${ }^{\mathrm{b}}$ Department of Information Technology \& Operations Management, Appalachian State University, Boone, NC 28607, USA \\ ${ }^{\mathrm{c}}$ Department of Management, Appalachian State University, Boone, NC 28607, USA
}

\begin{abstract}
Drawing on multiple sources, we identify technological, global and workforce trends that will affect the formulation and implementation of manufacturing strategy in the next decade. We then describe several theories from economics, sociology, and psychology and show how they can be used to enrich our interpretations of the effects of these trends. Throughout, we offer suggestions for future research in manufacturing strategy. (c) 2001 Elsevier Science B.V. All rights reserved.
\end{abstract}

Keywords: Change drivers; Manufacturing strategy; Technological trends

\section{Introduction}

At the dawn of the new millennium, several emerging and continuing trends point to a variety of fundamental changes central to manufacturing strategy. Many of these changes are technologically driven, and in some cases today's firms are already grappling with their effects. The rush to embrace and exploit supply chain management, for example, reflects both the increased penetration of inter-organizational information technology and the increased competitive pressure of today's markets. Other changes, such as shifts toward collaborative, knowledge-based work environments, have only just begun to take root in firms worldwide and may not reach their full impact until well

\footnotetext{
* Corresponding author. Tel.: +1-864-656-5963; fax: +1-864-656-2015.

E-mail addresses: scaron@clemson.edu (C.H. St. John), cannonar@appstate.edu (A.R. Cannon), pouderrw@appstate.edu (R.W. Pouder)

${ }^{1}$ Tel.: +1-828-262-2034; fax: +1-828-262-6190.

${ }^{2}$ Tel.: +1-828-262-2163; fax: +1-828-265-8685.
}

into the next decade. And, we should note, some of the changes promised by the new millennium may remain just that - promises.

Realized or not, however, these developments likely will result in order-of-magnitude increases in the uncertainty and complexity of manufacturing strategy formulation and implementation. The new millennium promises more demanding customers, greater competitive intensity, and increased complexity in production technology and coordination. What are the implications of these changes for the development of manufacturing strategy?

In this paper, we explore the predicted changes from several perspectives, using selected theories from economics, sociology, and psychology. In doing so, we hope to expand our understanding of the implications of these trends, and to identify research directions for manufacturing strategy researchers. The paper is organized as follows. In the first section, we synthesize predictions about trends that are affecting manufacturing firms. Second, we describe several theories from economics, sociology, and psychology 
that have been used only sparingly in manufacturing strategy research, then use the theories to provide a richer interpretation of the emerging trends in operations. We then conclude with some suggested research questions for manufacturing strategy researchers.

\section{Key trends driving change within manufacturing}

In 1997, the Agility Forum, with sponsorship from the National Science Foundation, published Next-Generation Manufacturing: A Framework for Action (Hughes, 1997). The four-volume publication documented the results of the Next-Generation Manufacturing (NGM) Project, which involved individuals from more than 100 companies, industry associations, academic institutions, and government agencies (see Table 1 for a list of participating individuals). As the project leaders noted in their summaries, advancements in technology are allowing critical business information to be available around the world instantaneously. Decision-makers can communicate with each other from any place at any time. These technology advancements are making time zones, national boundaries, and the physical location of management increasingly unimportant. Furthermore, improvements in transportation and increasing standards of living in most nations of the world are making the physical location of manufacturing facilities less important than in the past. Finally, as customers become more educated and improve their standard of living around the world, they will become more demanding of manufacturers.

The project task force summarized the drivers of change within manufacturing as follows: (1) ubiquitous availability and distribution of information, (2) accelerating pace of change in technology, (3) rapidly expanding technology access, (4) globalization of markets and business competition, (5) global wage and job skills shifts, (6) environmental responsibility and resource limitations, and (7) increasing customer expectations (Hughes, 1997, p. 3). Similar observations have been made by others, as well. In a survey of CEOs of US firms, almost $90 \%$ of those CEOs surveyed labeled "improving knowledge management and the use of information technology" as major trends at century's end (National Institute of Standards \& Technology, 1998).
What, specifically, will these changes mean for manufacturing? These more sophisticated and readily available information technologies allow firms to combine mechanisms for collecting information about customers (i.e. user profiles from e-commerce transactions, scanner data) with data mining and neural networks for pattern recognition, which will allow deeper understanding of customer behavior and more accurate forecasting. Lower cost, more sophisticated computer-integrated manufacturing techniques will allow more manufacturers to move toward mass customization. Advances in rapid prototyping processes will move that technology from predominantly a design tool to a tooling and production technique, which will also facilitate mass customization. Increased use of simulation testing of new products will allow much more rapid new product launch.

Web communications and web commerce will make new products known to a world market immediately. These technologies, working in concert, will collapse the time-span between the idea for the product and market launch to days, not months or years. Already firms are using CAD/CAM technology to facilitate rapid reproduction of their competitors' products (Quick, 1999), shrinking the window during which successful innovations can be exploited. Consequently, products will saturate the market and reach maturity much faster as informed, on-line customers react quickly to new product announcements. From the point of view of operations, these trends have implications for design-manufacturing integration (Cohen and Apte, 1997; Hauptman and Hirji, 1999; Hughes, 1997), dynamic capacity planning and scheduling, management of supplier networks, and workforce coordination across cultural and language barriers (Hauptman and Hirji, 1999).

In light of these technology and globalization trends, integrating activities both within and beyond organizational boundaries has become a major challenge at century's end and will likely continue for the foreseeable future (Mabert and Venkatraman, 1998). Integration efforts are expected to be focused both on internal activities, such as product and process design, and on fostering extra-organizational linkages with customers and suppliers. The explosion of interest in supply chain management in the last 2 years is evidence of this trend and its perceived importance in the current and future competitive environment. 
Table 1

NGM project participants

\begin{tabular}{|c|c|c|}
\hline Individual & Organization & Position \\
\hline Beck, J. & EMC Corporation & Vice President, Manufacturing \\
\hline Bescher, R.F. & Pratt \& Whitney & Vice President \\
\hline Bowen, $\mathrm{K}$. & Harvard Business School & Professor \\
\hline Buckland, A. & CP Claire Corp. & Chief Executive Officer \\
\hline Burtner, C. & Textron & Vice President, Human Resources \\
\hline Carlisle, B. & Adept Technology, Inc. & Chief Executive Officer \\
\hline Carlson, D. & Perceptron & President and Chief Executive Officer \\
\hline Commassar, D. & GE Aircraft Engines & General Manager \\
\hline D'Arbeloff, A. & Teradyne & Chief Executive Officer \\
\hline Davis, D. & The Stanley Works & Retired Chief Executive Officer \\
\hline Donaghy, J. & Sheldahl & President and Chief Executive Officer \\
\hline Erdekian, V. & Bay Networks & Vice President \\
\hline Farnum, S. & SK Williams Co. & Chief Executive Officer \\
\hline Fradin, D. & EMD Associates, Inc. & President \\
\hline Fuchs, D. & Allen-Bradley Company & Vice President for Corporate Development \\
\hline Gallello, D.J. & Autodesk & Vice President, Mechanical Market Group \\
\hline Garland, T. & EMC Corporation & Human Resources \\
\hline Glazer, L. & Michigan Futures & President \\
\hline Hawkinson, L.B. & Gensym Corporation & Chairman and Chief Executive Officer \\
\hline Holleman, E. & AFL-CIO (formerly, currently NIST) & Consultant, Industrial Union Department \\
\hline Hsu, J. & General Motors & Executive Director, Power Train and Strategic Futures \\
\hline Hyduk, S.J. (Bud) & Advanced Technology, EDS & Vice President \\
\hline Kelley, B.J. & Merck \& Co., Inc. & President, Manufacturing Division \\
\hline Kennedy, W. & The Sequoyah Group, LLC & President, Chief Executive Officer \\
\hline Kirby, C. & Hughes Electronic Co. & Corporate Vice President \\
\hline Lake, C. & FEI Company & Vice President, Manufacturing \\
\hline Lehmann, D. & Solar Turbines & Vice President and General Manager \\
\hline Lester, R. & MIT Industrial Performance Center & Faculty \\
\hline Lilly, D. & Lilly Software & Chairman and Chief Executive Officer \\
\hline Lyijynen, D. & Chrysler Corp. & Manager, Manufacturing Planning \\
\hline Meadows, D. & Lockheed Martin & Vice President \\
\hline Melia, K. & Manufacturers' Services Ltd. & President \\
\hline Melissaratos, A. & Westinghouse Electric Corp. & Vice President of Science, Technology and Quality \\
\hline Mittelstadt, E. & FANUC Robotics, N.A. & Chief Executive Officer \\
\hline Murphy, R. & Wheelabrator & Human Resources \\
\hline Nagey, S. & Chrysler Corp. & Manager, Executive Training and Manufacturing \\
\hline Nayak, R. & Arthur D. Little & Consultant \\
\hline Oldfield, J.R. & Polaroid Corp. & Executive Vice President, Photographic Imaging \\
\hline Potuondo, P. & Arthur D. Little (formerly) & Consultant \\
\hline Puffer, B. & Avid Technologies & Vice President, Operations \\
\hline Rock, $\mathrm{P}$. & Chrysler Corp. & Technology Development Executive \\
\hline Runkle, D. & General Motors & Vice President and General Manager \\
\hline Salzman, $\mathrm{H}$. & Jobs for the Future & Director of Research \\
\hline Scott, D. & Equipto & Vice President, Manufacturing \\
\hline Shumway, H. & Digital Equipment Corp. & Vice President \\
\hline Stander, B. & Prince Corporation & Vice President, Manufacturing \\
\hline Swanson, G.L. & Design and Manufacturing Corp. & President and General Manager \\
\hline Swindle, J. & Texas Instruments & Vice President, Manufacturing \\
\hline Terrell, D. & Sun Express & President \\
\hline Thurow, L. & MIT Sloan School & Professor of Management \\
\hline Tobin, J. & Siemens Corp. & Director, Technology Training \\
\hline Wheelwright, S. & Harvard Business School & Faculty \\
\hline Williams, L. & United Steel Workers Union & President (retired) \\
\hline Wright, B. & Nashua & Vice President, Human Resources \\
\hline
\end{tabular}


Information technology's role in supporting these integration efforts cannot be overstated; "much of the current interest in supply chain management is motivated by the opportunities that appeared due to the abundance of data" (Simchi-Levi et al., 2000, p. 11). With these data and the software packages to manage them, however, comes increased complexity (Mabert and Venkatraman, 1998).

Widespread adoption of Enterprise Resource Planning (ERP) systems are further evidence of information technology's role in coordinating between both internal and external activities. As the National Research Council has noted, however, "large companies have encountered significant difficulties in the integration of enterprise resource planning with their design functions" (National Research Council, 1998). Further, of late decision-makers have been confronted with reports of disastrous results from supply-chain related installations of ERP systems such as that which substantially disrupted Hershey Foods' shipments of candy during the holiday season of late 1999 (Sulon, 1999).

In addition to technology and information systems trends, the workforce of the new millenium promises to be much more specialized but also much more fluid. Some observers go so far as to predict that the corporation of tomorrow will actually be composed of only two functions - strategic planning and financial management - with all other human resource needs filled on an ad hoc basis from pools of specialized talent (Coates, 1999). While other human resource trend-watchers make less dramatic predictions, most agree that a successful firm in the next decade will avail itself of specialized and mobile labor pools to a much greater degree than its counterparts today (National Research Council, 1998). For example, in a survey of CEOs of large US firms, $71 \%$ of the respondents pointed out the increasing importance of managing part-time, temporary and contract workers as a major trend at century's end (National Institute of Standards \& Technology, 1998). A majority of the respondents (69\%) also emphasized the importance of using models of employer-employee relationships based not on tenure and/or lifetime employment, but on knowledge acquisition and actual performance (National Institute of Standards \& Technology, 1998).

In addition to being both specialized and mobile, the workforce is expected to be much more diverse demographically, ethnically and geographically. The continuance of these trends should affect job design, reward systems, and increase the difficulty of molding an effective organizational culture (Coates, 1999). A possible upside to this difficulty, however, would be the competitive payoff accruing to firms capable of establishing and maintaining knowledge supply chains (Hughes, 1997). Table 2 summarizes the trends, and some of their expected consequences.

\subsection{Implications for manufacturing strategy}

The principle facilitator of the trends discussed in the previous sections is information technology, which is changing the way firms communicate with and learn from customers, competitors, and supply partners, generally understood as primary sources of uncertainty (Porter, 1980). Information technology enables firms to partner with a broader set of constituents, leading to positions of greater security across more relationships (Pfeffer and Salancik, 1978).

It is generally understood that environmental uncertainty is a function of the availability and flow of resources (Dess and Beard, 1984). Environments characterized by rapid and/or discontinuous change in demand, resource availability or technology lead to contingencies that are difficult or impossible to anticipate but that managers nevertheless must consider when formulating and implementing strategy. Taken in isolation, then, these technology-driven trends suggest substantially decreased uncertainty in the next decade. In plotting their firms' futures, manufacturing strategists should be more certain about customer preferences, the capabilities of competitors (whether incumbent or potential), the universe of available technologies, and the availability and trustworthiness of potential partners. Further, increasingly global markets abetted by the push for free trade should reduce fluctuations in the availability of critical resources, be they physical, capital or human.

Ironically, however, in aggregate these trends promise the possibility of greater uncertainty for manufacturing strategists, since firms in the new century will be confronted with more complex environments. As firms increase the scope and distance of their activities, and work to include more constituents in their decision processes, they introduce additional 
Table 2

Drivers of change and their effects

$\begin{array}{ll}\text { Drivers of Change Effects of Change Drivers } & \end{array}$

\begin{tabular}{|c|c|}
\hline $\begin{array}{l}\text { Less expensive, more widely available communications, } \\
\text { information, transaction, and production technologies, such } \\
\text { as: } \\
\text { - Internet-based communications and commerce } \\
\text { - Data mining } \\
\text { - Pattern-recognition algorithms (neural networks, } \\
\text { - } \text { genetic algorithms) } \\
\text { - Ramputer integrated design } \\
\text { - } \text { Simulation testing of designs and prototypes } \\
\text { - Real-time data tracking } \\
\text { - Nanotechnology } \\
\text { - Elexible manufacturing technologies }\end{array}$ & 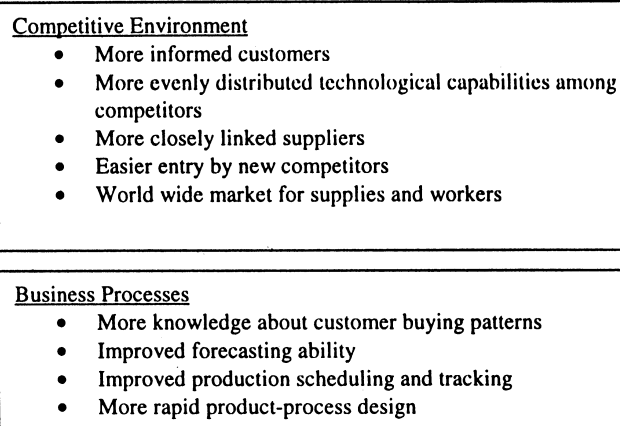 \\
\hline $\begin{array}{l}\text { Culturally, ethnically diverse workforce that is more mobile: } \\
\text { - Political and economic conditions creating more } \\
\text { opportunities for markets and supplies worldwide } \\
\text { - Aging workforce worldwide } \\
\text { - Language and culture differences }\end{array}$ & $\begin{array}{l}\text { Integration } \\
\text { - Coordination of geographically dispersed operations } \\
\text { - Coordination of culturally diverse workforce } \\
\text { networks of customers and suppliers } \\
\text { Workforce } \\
\text { - More use of temporary workers } \\
\text { - Competition for skilled and knowledge workers } \\
\text { - Management across national cultures }\end{array}$ \\
\hline
\end{tabular}

complexity (Dess and Beard, 1984). Much of this increase will be attributable to the exercise of strategic choice and the deliberate attempt by firms to partner via technology with more constituents as a means of reducing uncertainty on a relationship-by-relationship basis (Pfeffer and Salancik, 1978). For example, as information technology allows firms to coordinate more closely with supply chain partners, it becomes easier to coordinate with more and different supply chain partners - which, over time, increases the complexity and ultimately the uncertainty faced by the firm (Gibbs, 1994). Increased complexity is accompanied by a wider variety of contingencies that must be evaluated. Thus, as firms increase the number of environmental sectors upon which they depend, they also increase the probability that an unfavorable contingency will emerge from one or more of those sectors. Also driving this increase in complexity will be competitive dynamics that impel firms to tap fun- gible and specialized labor or knowledge pools on ad hoc bases (Coates, 1999).

As described, technological advances, particularly in information technology, coupled with globalization and workforce issues are driving changes in manufacturing. In that they influence the behavior of customers and competitors, opportunities for achieving and sustaining competitive advantage, and the complexity of managing and coordinating manufacturing, these changes will have implications for the development of viable manufacturing strategies. Conceptual models and theories that address industry dynamics, competitive advantage, and inter- and intra-organizational processes will likely find more direct application in manufacturing strategy research as these trends become more pronounced.

Amundson (1998) has argued that operations management should look to other fields for theories. As she noted, "operations management lags disciplines such 
as sociology and economics in the creation of formal, research-oriented theoretical perspectives ... it is important to examine theorizing in other fields... By learning from other disciplines, operations management can exercise prudence without painfully 'reinventing the wheel"'. Several researchers in operations strategy have already applied some promising theories from economics, including (1) industrial organization and resource dependency theories, as captured by the widely used Porter model, and (2) the resource-based view, which has been used to explain sources of competitive advantage. Just-in-time manufacturing, for example, has been examined both from the resource dependency perspective by Handfield (1993) and the resource-based view by Cowton and Vail (1994), but other change movements and broad competitive initiatives are as yet generally unexamined by theories from the social sciences. In the next section, we will describe some of the most promising theories from economics, sociology, and psychology and show their potential for informing the manufacturing strategy challenges that are on the horizon.

\section{Theoretical foundations for manufacturing strategy}

The role of the production system as a determinant of organization capability and performance was the subject of organization research for decades, long before the concept of a manufacturing strategy was defined explicitly. The focus of most early work conducted within the organization sciences was on the impact of the organization's production task and technology on its structural characteristics (Gerwin, 1981). Woodward (1958), Thompson (1967) and Lawrence and Lorsch (1967) and many others found evidence of the important relationship between production technology and the organization's structure and control systems. As technologies within production become increasingly routine, structure and control processes tend to become more formal and mechanistic; as technologies become more flexible, structure and control become less formal and more organic.

An assumption underlying most early work was that the production core had one task - to move toward the most efficient, low-cost state by investing in automation and standardization in response to predictably ma- turing markets. In the 1960s and early 1970s, Skinner $(1969,1974)$ made persuasive arguments that the production system, rather than always seeking efficiencies, should reflect the priorities of the organization. His arguments for a contingency-based manufacturing strategy spurred a generation of interest in interactions among environment, organization strategy, and operations. Examples of some key contributions in those areas are shown in Table 3 .

Several theories from economics, sociology, and psychology show significant promise for manufacturing strategy researchers. The theories explore issues in industry and competitive dynamics, competitive advantage and strategy development, and inter- and intra-organizational coordination, and management decision processes. Some of the most promising are described in the following sections.

\subsection{Resource-based view}

The resource-based view (RBV) of the firm provides interesting insights into the role of operations strategy in creating firm-level competitive advantage. The RBV helps clarify the types of strengths and capabilities that will have value and lead to strategic advantage (Barney, 1991; Grant, 1991; Mahoney and Pandian, 1992). Within the resource-based view, resources and capabilities that can lead to competitive advantage are those that are valuable and non-substitutable, from the point of view of customers, and unique and inimitable, from the point of view of competitors (Barney, 1991; Grant, 1991). Within this framework, the manufacturing strategy task is to build capabilities over time as a mechanism for enacting the environment and for creating isolating mechanisms that buffer the firm from imitation (Rumelt, 1984). Within the resource-based framework, the resources and capabilities of manufacturing - if they are unique, valuable, non-substitutable, and inimitable - would lead the strategy of the firm, consistent with the stage four operations described by Hayes and Wheelwright (1984). The organization would adjust its strategy and resource allocations in order to support, protect, and leverage the unique capabilities of manufacturing.

The resource-based theory of the firm is useful in explaining the role of manufacturing in creating and sustaining competitive advantage. As noted by Teece 
Table 3

Operations strategy research themes

\begin{tabular}{|c|c|}
\hline Theme & Examples \\
\hline Fit between the production core and the organizational environment & $\begin{array}{l}\text { McDougal et al. (1992) } \\
\text { Nemetz and Fry (1988) } \\
\text { Swamidass and Newell (1987) } \\
\text { Van Dierdonck and Miller (1980) } \\
\text { Vickery et al. (1993) } \\
\text { Ward et al. (1994, 1995) }\end{array}$ \\
\hline Fit between the production core and the strategies of the firm & $\begin{array}{l}\text { Kim and Lee (1993) } \\
\text { Kotha and Orne (1989) } \\
\text { McDougal et al. (1992) } \\
\text { Schroeder et al. (1995) } \\
\text { Sweeney (1991) } \\
\text { Williams et al. (1995) } \\
\text { St. John and Harrison (1999) }\end{array}$ \\
\hline Internal consistencies among elements of the core & $\begin{array}{l}\text { Kim and Lee (1993) } \\
\text { St. John and Young (1992) } \\
\text { Vickery et al. (1993) } \\
\text { St. John and Harrison (1999) }\end{array}$ \\
\hline The dynamic relationship between operations and the organization as markets and products mature & $\begin{array}{l}\text { Abernathy and Townsend (1975) } \\
\text { Abernathy and Utterback (1978) } \\
\text { Hayes and Wheelwright }(1979 a, b) \\
\text { Kim and Lee (1993) } \\
\text { Pearson et al. (1991) }\end{array}$ \\
\hline
\end{tabular}

et al. (1997), fixed assets such as plant and equipment often may be purchased by all industry participants and, therefore, rarely serve as a source of competitive advantage. On the other hand, firm-specific resources, such as knowledge or complex processes and routines, may serve as a source of advantage. Furthermore, advantages derived from manufacturing routines and processes may be more difficult for competitors to imitate than other organizational resources and capabilities. The internal workings of manufacturing are not readily observable, and are usually protected through security procedures and confidentiality agreements. Custom designed process equipment, worker experience, and the accumulation of incremental process improvements made over time can create a store of firm-specific manufacturing capability that is difficult to observe and almost impossible to imitate (Abernathy and Utterback, 1978; Hayes and Wheelwright, 1984). The causal ambiguity created by these complex systems and routines is one of the cornerstones of competitive advantage within the resource-based view in that it provides for inimitability (Barney, 1991).
Although many interpretations of the resource-based view of the firm treat organizational knowledge as an intangible resource, as in the Teece et al. (1997) work above, some researchers advocate development of a separate theory of the firm as a body of knowledge (Spender, 1996). Organization learning and absorptive capacity (i.e. the processes through which knowledge is accumulated from sources inside and outside of the firm, retained and preserved, and then applied to a new situation) are related areas of inquiry that help augment our understanding of the role of human knowledge in the development of firm-level capabilities and performance (Cohen and Levinthal, 1990; Leonard, 1995).

Several researchers have already identified opportunities to apply RBV concepts to manufacturing strategy issues. Teece et al. (1997) used the arguments of the RBV in explaining decisions to vertically integrate, and in describing dynamic capabilities. Cowton and Vail (1994) used the RBV to guide their mapping of just-in-time manufacturing practices. Also, St. John and Harrison (1999) used the RBV to argue that 
manufacturing has substantial potential to serve as the basis for corporate level distinctive competence when synergy is achieved among manufacturing-related business units.

\subsection{Industrial organization}

Although there are at least five distinct schools of thought within the IO field - neoclassical economics, Bain/Mason structure-conduct-performance (SCP) models, Schumpeterian economics, the Chicago tradition and the Coase-Williamson transactions cost perspective - the SCP paradigm and the transaction cost perspective both offer much to manufacturing strategy researchers. The SCP paradigm (Porter, 1981) proposes that a firm's performance depends on the characteristics of the environment in which it competes. Industry profitability is determined by industry structure, which is a function of barriers to entry, number and size of competing firms, demand elasticity, and differences among competitors, and other characteristics. The SCP paradigm provides its major contribution in framing the sources of environmental influence over industry profitability, explicating the role of entry barriers, and then explaining the degree to which imitative competitive behavior can drive down overall industry profits.

Manufacturing strategy researchers have applied the SCP paradigm through the Porter Five Forces model, which combines elements of the SCP paradigm with resource dependency theory. The Porter model has been used to describe the attractiveness of industries, the role of entry barriers, and the actions of competitors. For example, scale efficient facilities, investments in leading-edge technologies, and accumulated industry- and technology-specific knowledge can serve as barriers to entry, creating friction and costs that restrict or slow movement into an industry. The SCP model may also be used to demonstrate the strategic ramifications of production technology, particularly the tradeoff between flexibility and efficiency at a given level of market power (Mills, 1984; Mills and Schumann, 1985; Carlsson, 1989).

The transaction cost perspective offers insights into several of the issues within manufacturing strategy and has been thoroughly applied by economists to make-versus-buy decisions and use of alliances. According to Williamson (1975), firms are likely to vertically integrate in order to conduct in-house those transactions that are subject to uncertainty and that require substantial investment in assets that are difficult to deploy elsewhere. On the other hand, transactions that are subject to less uncertainty and involve general-purpose investments are more likely to be conducted in the market. The implications of these findings, when considered in light of the resource-based view, is that vertical integration is intended to reduce environmental uncertainty and is associated with transaction-specific investments, which may provide firm-specific advantages. In recent years, researchers have modified the transaction cost arguments to account for networks or alliances (Pisano, 1990). For example, Pisano (1990) used the transaction cost perspective to examine the propensity of firms to develop new competence-destroying technologies in-house versus contracting with research firms.

\subsection{Resource dependency theory}

This theory base takes the position that an organization's environment is inherently unstable (Pfeffer and Salancik, 1978) but that organizations may act to reduce vulnerabilities and to increase their own power relative to constituents. The degree to which the organization is dependent upon, and thus vulnerable to, external resources is determined by the importance of the resource, the organization's discretion over it, and the extent to which there are alternatives to choose from (Handfield, 1993).

Even though the production core is often conceptualized as an open system subject to influence by the environment, the tradition in production has been to limit vulnerability to resource variability by buffering the core from uncertainty whenever possible (Nemetz and Fry, 1988; Thompson, 1967). Resource dependency theory offers insights into this logic. In resource dependency theory, organizations seek to decrease their dependence on others, and will alter their structures and patterns of behavior in order to acquire and maintain access to external resources (Pfeffer and Salancik, 1978; Ulrich and Barney, 1984). This theory is particular relevant for manufacturing, which has a tradition of creating buffering departments and roles. For example, the creation of a purchasing department buffers operations from the uncertainty of supply arrangements, and the creation of a human resources department buffers 
operations from the uncertainties of the labor market (Daft, 1989). Buffering strategies may take the form of structural solutions such as vertical integration to guarantee an essential resource, automated processes to reduce dependency on skilled labor, or planned excess capacity to buffer demand uncertainty. Buffering strategies may also take the form of infrastructural solutions such as inventory-holding policies, safety stocks and safety lead times, modular designs, preventive maintenance, and worker cross-training which are all intended to buffer the core from unexpected events and to ensure efficient use of core technologies (Thompson, 1967).

As we increasingly observe, an alternative or supplement to buffering is to use bridging strategies to span boundaries. These are typically used when there is a high level of uncertainty associated with organizational interdependence. Bridging strategies seek mutual control and cooperation (Pfeffer and Salancik, 1978); examples include contracting with suppliers, strategic alliances and joint ventures to pool innovative talent, and formal coalitions such as trade associations, and vertical mergers. Supply chain management is an example of a bridging strategy for reducing uncertainty.

Handfield (1993) applied resource dependency concepts in his study of supply relationships, noting a tendency for make-to-order firms to reduce the number of critical suppliers when confronted with demand uncertainty. Whereas firms narrowing their supply base become more vulnerable to the bargaining power of those remaining vendors (Porter, 1980), Handfield noted compensating reductions in uncertainty in a variety of other areas (Handfield, 1993).

\subsection{Institutional theory}

The primary thesis of institutional theory is that organizations must conform to the established rules and norms of dominant institutions in order to gain support and be perceived as legitimate (Baum, 1996). From the point of view of a manufacturing firm, key institutions that work to establish norms include regulatory agencies, quality norms such as ISO certifications, suppliers, customers, professional organizations, and even competitors. As institutions establish norms and routines within an industry, firms that adopt those standards tend to become more similar over time.
When faced with complexity and uncertainty about technologies and markets, firms often choose to engage in imitation, which leads to mimetic isomorphism (DiMaggio and Powell, 1983). To cope with uncertainty, firms will economize on search costs (Cyert and March, 1963) and imitate the actions of other organizations (Haveman, 1993). Within operations, the tendency for firms within an industry to move toward standard products, similar process technologies, and similar degrees of vertical integration is evidence of mimetic isomorphism. Similarly, the widespread adoption of JIT and TQM, fueled by same-industry benchmarking, are evidence of the same phenomenon.

Coercive isomorphism occurs when organizations are required to comply with procedures, controls, and structures imposed from outside the firm (DiMaggio and Powell, 1983). Requirements to comply with regulatory agencies, financial reporting standards, and externally imposed quality standards such as ISO 9000 are examples of coercive forces that work to create sameness among competitors and result in standardized products, processes, and information flows within operations.

In some industries, manufacturing may be susceptible to pressures from another form of isomorphism normative (DiMaggio and Powell, 1983). If many of the process engineers, managers, researchers and new employees are from similar educational backgrounds, educational institutions, and industry experiences, they will tend to define problems and filter information in the same way (DiMaggio and Powell, 1983). These similarities in background and experience tend to create similar cognitive frameworks, or mental models, that work to create homogeneity over time (Walsh, 1985).

Institutional theory is rarely used in the study of manufacturing strategy issues, yet it holds great promise in explaining why the production cores of competing firms are so often similar, why generic improvement programs are so readily adopted, and the role of suppliers, customers, and other external constituencies in driving the sameness that undermines opportunities for competitive advantages. As manufacturing organizations seek tighter relationships with external constituents, through initiatives such as supply chain management and the attendant integrated computer systems, they will be further pressured to employ technologies, policies, and procedures that 
are compatible with other firms in the network, thus creating homogeneity.

\subsection{Cognitive theory}

Unlike the previous theories, which pertain to industry and firm-level analyses, cognitive theory offers insights into the decision-making processes of managers. According to behavioral decision theory, managers develop their own cognitive representations of reality called cognitive schema or mental models (Kiesler and Sproull, 1982; Porac and Thomas, 1990). Schema and mental models provide frames of reference for storing information and knowledge acquired through education and experience. An individual's mental model might reflect firm beliefs about customer expectations, the expected actions of competitors, the role of manufacturing in strategy making, opportunities created by technology, and societal obligations toward other cultures and the natural environment. Mental models allow decision makers to see similarities between different situations at different points in time, which can reduce cognitive complexity and speed decision processes. Mental models, when appropriately aligned with decision stimuli, can help decision makers rule out extraneous information and focus on relevant issues - thus expediting decision making without sacrificing decision quality (Mintzberg et al., 1976). For example, Tyler and Steensma (1998) found that executives with technical education and past success with collaborative technological developments were more likely to focus on the opportunities presented by inter-firm technology alliances than other managers, who tended to focus on the risks.

It is common, however, for mental models to become rigid and out of synchronization with environmental realities, leading to biased, over simplified decisions (Tversky and Kahneman, 1986). The complexity and uniqueness of strategic decision-making makes it an especially attractive candidate for bias (Schwenk, 1984). The increased complexity of the decision making environment of the next decade presented by rapid technology changes, more demanding customers, more able competitors, and increased demands for worldwide integration suggests many opportunities to apply cognitive theory to manufacturing strategy decision making.

\section{Framing a manufacturing strategy research agenda}

In this section, returning to the change themes described in the earlier sections, we consider how the various theories can help us in interpreting these trends and in framing a manufacturing strategy research agenda for the next decade. As noted by others, however, the true test of any theory is its applicability in answering questions; "good theory is ultimately practical" (Melnyk and Handfield, 1998, p. 312). Thus, the degree to which these and other theories will be useful in studies of manufacturing strategy depends on the degree to which they can be successfully applied to key manufacturing and operations imperatives that are emerging. The theories, when considered in combination, provide an opportunity to see the effects of the trends from multiple perspectives.

\subsection{Competitive environment and business processes}

According to most interpretations, as described earlier, the future will involve much more rapid product-process realization, pervasive use of neural network-based data analysis and simulation modeling, and adaptive responsive information systems (Hughes, 1997). Computer-aided design, rapid prototyping, and simulation testing will work in concert to cut product and process development lead times to a fraction of what they are now. Further, use of web-based communications and commerce will facilitate coordination among units at disparate locations.

Boeing's development of its 777 jetliner is illustrative of these developments. Boeing used electronic communications to integrate dozens of design-build teams across the world that were involved with the extremely complex project (Hughes, 1997), and the entirely digitized design enabled simulation testing that cut months off the development and certification timeline (Woolsey, 1997). Broader use of technology in monitoring production also will enable firms to share information from their production and control systems with sales representatives and customers on a global basis. Becton Dickinson, for example, has used integration software and a supply-chain focused organizational structure to couple its production and distribution efforts more closely with the needs and wants of its customers (LaHowchic, 1997). 
What are the implications of these technology trends for the study of competitive advantage and manufacturing strategy? Given trends in technological diffusion, some sources of advantage today may become so inexpensive and readily available as to level the production playing field for all comers, regardless of size and experience. Differentiating features and competencies likely will be imitated quicker and cheaper in the new millennium, forcing firms to become more agile and responsive in order to survive.

The SCP paradigm suggests to us that technological advances predicted for the future will reduce barriers to entry and undermine manufacturing scale effects, which will allow new entrants and imitators to enter and respond quickly. Therefore, the concepts of "first to market" and scale effects will have less meaning in the future as vehicles for competitive advantage, which will allow new entrepreneurial firms to make significant inroads against established competitors. As a result, industries will be even more intensely competitive than they are now, with substantial pressures on profitability. This is not to say that all industries would be equally competitive or would undergo the same rate of change. Industries evolve at different rates and experience different average levels of profitability, and will continue to do so in the future. But, compared to now, each industry would be more competitive and faster paced.

The resource-based view (RBV) provides a complementary perspective on ease of imitation and its consequences. Although unique, valuable resources are the key to competitive advantage in the RBV, low-cost, widely available technologies will make imitation of many resources and capabilities easier, and advantages will be shorter lived. Sustainable difference, or competitive advantage, will likely not manifest itself in a particular proprietary product design as it could be readily imitated using technology. Instead, it is likely that competitive advantage will be derived and sustained through causal ambiguity, i.e. from complex organizational routines and knowledge that provide unique capabilities unobservable to competitors. As noted by Powell and Dent-Micallef (1997) in their study of information technology and its role in competitive advantage, technology driven differences are easy to imitate and incapable of providing sustainable advantages. Advantages must be created instead by leveraging technologies with other human and business resources that are more difficult for competitors to observe. For example, rapid prototyping and simulation testing could be combined with a uniquely qualified, well-managed design team capable of staying one step ahead of the competition with each new design. The product design would not provide a sustainable advantage, but the ability to continuously create new designs - an organizational capability subject to causal ambiguity - would. These issues suggest opportunities for researchers to investigate the complex interactions between advanced design and manufacturing technologies, accumulated knowledge, management activities, and competitive advantage created within manufacturing.

Although advantage will continue to be derived from sustainable differences that have value to customers, manufacturing's role in creating and sustaining those differences may change as well. If technology-driven low entry barriers allow small manufacturing firms to thrive, the implications are that there will be a thriving market for efficient manufacturers. Transaction cost theory would suggest, then, that larger firms would be likely to make more use of contract manufacturing activities, with many, competitive suppliers available to substitute for in-house production. In addition to being more likely to engage in contract manufacturing and other forms of outsourcing, larger firms also would be expected to be more successful in their efforts to control their sourcing partners, a conclusion consistent with resource dependency theory. Resource dependency theory also would be useful for framing research questions into shifts in the balance of power between firms and customers brought about by decreased informational asymmetry; as customers make better use of information technology, they become better informed and are more capable of effective bargaining.

From an institutional theory perspective, as imitation becomes necessary to keep up, firms should exhibit evidence of mimetic isomorphism, becoming more alike in the structural elements of their operations strategies. Also, from an institutional theory perspective, the increased scope of supplier and customer networks may increase opportunities for knowledge spillovers and pressure for isomorphism.

Research in cognitive theory and management decision-making has shown that a manager's education and past experiences will influence his or her per- 
ceptions of environmental stimuli and the availability and relative attractiveness of strategic alternatives (Kiesler and Sproull, 1982; Porac and Thomas, 1990). In an environment of rapid technological change and collapsing life cycles, manufacturing managers who have formed mental models in more stable times will likely face difficulty in the more fast-paced decision environment of the next decade. Manufacturing firms will need managers who understand technologies, can tolerate ambiguity and quickly recognize emerging opportunities, and can rapidly implement changes.

\subsection{Integration between enterprises}

As described, the opportunities presented by technological advances will increase the need to integrate effectively within and between enterprises. Firms will likely outsource more activities, which will create a need to coordinate with more elaborate, complex supplier networks. Customers will be more knowledgeable about competing products and will be more demanding, which will cause firms to create tighter linkages and provide rapid responses, consistent with resource dependency theory. Although communications technologies will make these relationships possible, management will be further complicated by their sheer numbers as well as cultural differences and distance.

The resource-based view and transaction cost theories offer complementary views of the future of competitive advantage, which are contradicted by some of our understanding of the SCP paradigm from industrial organization economics. When coupled with the premises of the resource-based view, the choice of which activities to internalize will be made more complex and consequential by the recognition that conducting activities in-house may be the best way to preserve or cultivate unique capabilities and to avoid opportunism by other enterprises. Given rapidly evolving markets, however, manufacturers will have to make a delicate tradeoff between the efficiencies of the open market - in which outsourcing to specialists will become more compelling and the value of controlling these activities in-house. Although transaction costs and the resource-based view would suggest that unique, specific resources should be maintained in-house, the lower entry barriers, improved ability to forecast customer demand, and increasingly imitative behaviors of competitors, as predicted by industrial organization and institutional theories, would suggest that the uniqueness of resources might be difficult to preserve and that outsourcing might be a viable alternative.

Transaction cost theory provides additional insights into inter-firm relationships. In environments of increasing demand certainty — as predicted by the tighter linkages with customers - firms are more likely to outsource production activities. Transaction cost theory also cautions against the risks of opportunistic behavior on the part of suppliers and alliance partners (Robertson and Gatignon, 1998; Williamson, 1975), with these concerns confirmed across several settings including production processes (Monteverde and Teece, 1982), domestic distribution (John and Weitz, 1988), and international distribution (Klein et al., 1990). These concerns suggest ripe research opportunities for investigating the management methods that work to balance the interests of constituents and that curb opportunistic behaviors, and the degree to which they are influenced by culture, distance, and type of coordinating mechanisms.

In deciding what activities to outsource to other firms, resource dependency and resource-based views offer insights that can complement the transaction cost perspective. Generally, firms are stuck with their resource endowments in the short run (Teece et al., 1997) and, in line with the resource-based view, may choose to source from a partner in order to get fast access to potential scarce and valuable assets. Resource-poor firms may be motivated in the longer run to bring assets in-house in an attempt to build a source of competitive advantage. Similarly, firms that have succeeded in cultivating unique, valuable resources are unlikely to outsource those activities for fear that they will be imitated, even if outsourcing would lower the transaction costs.

In a review of inter-organizational linkages, Auster (1994) calls for research that incorporates cognitive and learning perspectives. Cognitive theory offers insights about inter-organizational linkages from manufacturing's point of view through the concept of cognitive sunk costs (Powell, 1991). Cognitive sunk costs refer to the social and technological costs associated with altering habits and routines such that firms fail to seek economically feasible alternatives (Powell, 1991). Examples include reluctance to abandon a 
poor performing supplier or to discontinue a research collaboration that has evolved over several years. For example, Leonard-Barton (1992) observed how the cultures of chemical companies valued chemical engineers over mechanical engineers, which led to support for projects that involved polymers over mechanical equipment. Mechanical equipment projects would be more likely to be outsourced.

In line with institutional theory, these kinds of decisions take on a "taken-for-grantedness" (Oliver, 1997, p. 700) such that there is no apparent economic or technical rationale. As she notes, "A firm, for example, that retains the same unreliable supplier over a period of years may be perpetuating this institutionalized activity simply out of habit... When managers justify actions with the claim that 'we've always done it this way', 'everybody does it this way', or 'that's just the way things are done around here', they are referring to institutionalized activities". For example, if manufacturing management has never had to work with international suppliers, entrenched, institutionalized mental models may color their ability to evaluate that option appropriately.

Institutional forces are likely to manifest themselves in the use of enterprise software to coordinate among the various activities of the firm. Instead of formulating customized solutions for specific settings, however, firms are showing a tendency to modify their design parameters to meet the performance of off-the-shelf systems and to make their systems compatible with others in their network. In essence, then, enterprise software purchased from an external vendor is becoming a standard platform upon which organizational structure and cross-boundary relationships are based. In addition to the increased rapidity of diffusion of innovations - skills and competencies will remain proprietary only briefly - common-platform enterprise computing could become another significant source of institutional normative isomorphism. That is, operations-specific initiatives will be evaluated not only by their technical or competitive merits, but also by their congruence with institutional norms erected and enforced by third parties such as software vendors or enterprise computing consultants.

Furthermore, ERP systems create a source of dependency within organizations - by, in essence, creating an extraordinarily powerful supplier. If pro- duction planning, accounting systems, personnel systems, and order processing are operated with separate computer systems, then one system can fail without causing a collapse of the entire system. The system is, in essence, buffered. As recent experience with Hershey shows, vulnerability increased as the power and influence of the ERP increased, consistent with the resource dependency view. These events and theoretical perspectives suggest intriguing research questions and alternative explanations about the risks and rewards of ERP systems.

\subsection{Workforce issues}

According to findings of the NGM project (Hughes, 1997), members of the workforce - particularly technologically sophisticated specialists - will become increasingly mobile. Knowledge workers, designers and thinkers will be hired episodically rather than permanently. This trend implies a virtual or fungible workforce available on the open market for firms' intermittent needs. This phenomenon is the manifestation of a classic transaction cost theory issue. For workers that do not have unique skills and that are readily available, i.e. unskilled workers, transaction cost theory prescribes the use of temporary and part-time workers as needed. On the other hand, some knowledge workers possess firm-specific knowledge that may serve as the basis for advantage. In those circumstances, particularly if the knowledge workers are difficult to find, transaction cost theory would argue for ownership, i.e., extraordinary efforts to ensure employee.

Institutional theory also offers insights into an increasingly mobile workforce. It suggests that such a workforce will increase isomorphism among firms, as workforce members see themselves more as members of a profession - with norms to which they willingly subscribe - and less as employees of a firm. In essence, knowledge workers would operate largely as consultants. From the point of view of resource-based theory, mobility would undermine competitive advantage by eliminating the accumulation and retention of knowledge as a firm-specific intangible asset. Proprietary knowledge and expertise would dissipate rapidly as employees move from company to company, as observed in Silicon Valley, and other high technology clusters. 
To the degree that mobility leads to isomorphism, however, such an environment may be a welcome development for some manufacturers. Normative isomorphism can expedite the learning process for firms, making required skills, knowledge and routines readily available on open markets and allowing entry of new firms. Further, resource dependency theory leads to the conclusion that contracting of knowledge workers on the open market will make firms more vulnerable to the bargaining power of professional blocs.

Cognitive theory provides a possible check on these trends, however. Although many knowledge areas appear to be in a process of professionalization, individuals within these areas - particularly in engineering and computers - are increasingly from non-Western backgrounds. Heterogeneous backgrounds could disrupt homogeneous mental models and slow the normative isomorphism that accompanies the professionalization of a field.

Cognitive theory also suggests that employees who move from one firm to another are less likely to develop entrenched mental models that are resistant to new information. On the other hand, tolerance for ambiguity and change, which would be requisite in a mobile workforce, could lead to more innovative mind-sets, or just more impatient decision-making, depending upon the specifics of the situation. To the degree that employees do not identify themselves with the long run future of an organization, it is possible they will exhibit a short-run decision horizon reducing commitments to long run projects.

Some of these complications are likely to be short-lived, however. The resource-based view, and our understanding of accumulated knowledge as the basis for advantage, suggest that management will be forced to counteract the mobile workforce trend through more aggressive and attractive employment arrangements and benefits. Knowledge workers will be highly prized. Although there will be opportunities that will allow mobility and treatment of knowledge workers as a temporary workforce, that instability will be inherently unattractive for firms and for the knowledge workers themselves. It is likely that firms will establish attractive arrangements to retain the best workers, allowing them complete flexibility to live and work where and when they want.

The linkages between trends and theories discussed in this section are summarized in Table 4.

\section{Implications and suggestions}

In prefacing a special Journal of Operations Management forum on theory-driven research, Melnyk and Handfield point out that "the class of problems facing operations managers today is often less well-defined" than ever before (Melnyk and Handfield, 1998, p. 312). In this paper, we have attempted to interpret the drivers of change in manufacturing using multiple theoretical perspectives - all in an attempt to better define the issues and problems that manufacturing managers, and manufacturing strategy researchers, will encounter in the future. In our interpretations in this article, several themes emerged that frame interesting research questions for manufacturing strategy scholars.

\subsection{Manufacturing scope and advantage}

As we have discussed, the lower cost and widespread availability of communication, design, and production technologies will decrease demand uncertainty and simultaneously lower entry barriers to new competitors. These trends suggest several research questions about the effect of these industry characteristics on manufacturing firms. One compelling set of questions pertains to manufacturing scope. A lowering of entry barriers will make entry by new firms likely, but it will also make movement into new areas easier for incumbent firms. To what degree will incumbent manufacturing firms be compelled to take advantage of lower entry barriers and easy-to-access new technologies to diversify into different products and markets, thus enlarging scope? What will be the trade-off between the ease of entry and the increasing complexity, and accompanying increase in uncertainty, associated with these moves? What will be the implications of these likely scope-enlarging moves on facility design, incoming and outgoing logistics, and internal coordination? Is it possible that the manufacturing advantages derived from more certain markets and advanced technologies will be compromised by corporate and business-level strategies that increase scope, complexity and uncertainty? Or, will there be opportunities to derive competitive advantage through superior coordination of complex manufacturing environments?

A second compelling set of questions relates to manufacturing advantage. In an environment of in- 
Table 4

Using theories to frame the effects of trends

\begin{tabular}{|c|c|c|c|c|c|c|}
\hline & Industrial organization & $\begin{array}{l}\text { Transaction cost } \\
\text { theory }\end{array}$ & Resource-based view & $\begin{array}{l}\text { Resource dependency } \\
\text { theory }\end{array}$ & Institutional theory & Cognitive theory \\
\hline $\begin{array}{l}\text { Competitive } \\
\text { environment }\end{array}$ & $\begin{array}{l}\text { Lower barriers to } \\
\text { entry } \\
\text { Reduced scale effects } \\
\text { Faster imitation } \\
\text { More intense price } \\
\text { competition }\end{array}$ & $\begin{array}{l}\text { Less demand uncertainty } \\
\text { from closer ties to } \\
\text { customers could lead to } \\
\text { more outsourcing }\end{array}$ & $\begin{array}{l}\text { In an environment of rapid } \\
\text { imitation, competitive } \\
\text { advantages will be derived } \\
\text { from causal ambiguity, } \\
\text { embedded knowledge and } \\
\text { complex routines }\end{array}$ & $\begin{array}{l}\text { More informed and } \\
\text { powerful customers }\end{array}$ & $\begin{array}{l}\text { Less expensive and risky } \\
\text { imitation }\end{array}$ & $\begin{array}{l}\text { Managers develop mental } \\
\text { models of their industries } \\
\text { (beliefs about competitors, } \\
\text { customers, and } \\
\text { technologies) that influence } \\
\text { decision making in } \\
\text { subsequent time periods, } \\
\text { even if conditions change }\end{array}$ \\
\hline $\begin{array}{l}\text { Business } \\
\text { processes }\end{array}$ & Shorter product life cycles & $\begin{array}{l}\text { Outsourcing of non-critical } \\
\text { processes }\end{array}$ & $\begin{array}{l}\text { Advantages based on } \\
\text { technology and designs will } \\
\text { be shorter lived }\end{array}$ & $\begin{array}{l}\text { More opportunities for } \\
\text { influence by suppliers of } \\
\text { outsourced processes }\end{array}$ & $\begin{array}{l}\text { Trend toward } \\
\text { homogenization of } \\
\text { structural elements of } \\
\text { manufacturing for firms } \\
\text { within industries from } \\
\text { off-the-shelf technologies } \\
\text { and information systems } \\
\text { (mimetic isomorphism) }\end{array}$ & $\begin{array}{l}\text { Managers and employees } \\
\text { will differ in their ability to } \\
\text { adapt to new technologies } \\
\text { and processes, depending } \\
\text { upon their past experiences } \\
\text { and education }\end{array}$ \\
\hline Integration & $\begin{array}{l}\text { Need for tighter } \\
\text { coordination between } \\
\text { product-process design to } \\
\text { keep up with competitive } \\
\text { intensity }\end{array}$ & $\begin{array}{l}\text { Provide mechanisms for } \\
\text { curbing opportunism by } \\
\text { external constituents }\end{array}$ & $\begin{array}{l}\text { Choice of which activities } \\
\text { to outsource would be } \\
\text { determined by opportunities } \\
\text { to create/preserve } \\
\text { uniqueness rather than costs } \\
\text { Difficulties in accumulating } \\
\text { knowledge across disparate } \\
\text { units around the world }\end{array}$ & $\begin{array}{l}\text { More extensive networks of } \\
\text { customers and suppliers } \\
\text { will increase complexity, } \\
\text { creating pressures to instill } \\
\text { more bridging mechanisms }\end{array}$ & $\begin{array}{l}\text { Outsourced activities and } \\
\text { networks provide more } \\
\text { opportunities for imitation } \\
\text { (coercive isomorphism) }\end{array}$ & $\begin{array}{l}\text { Mental models developed } \\
\text { from functional experience } \\
\text { and cultural background will } \\
\text { influence ability to integrate } \\
\text { across functions and cultures }\end{array}$ \\
\hline \multirow[t]{2}{*}{ Workforce } & $\begin{array}{l}\text { Competition for } \\
\text { skilled/knowledge workers } \\
\text { will drive up wage rates }\end{array}$ & $\begin{array}{l}\text { Increased reliance on } \\
\text { temporary workforce in low } \\
\text { skill areas }\end{array}$ & $\begin{array}{l}\text { Difficulties in accumulating } \\
\text { and retaining firm-specific } \\
\text { knowledge }\end{array}$ & $\begin{array}{l}\text { Vulnerability to scarcities in } \\
\text { skilled/knowledge workers }\end{array}$ & $\begin{array}{l}\text { Opportunities for knowledge } \\
\text { spillovers and dissipation of } \\
\text { unique knowledge from } \\
\text { mobile/transient workforce }\end{array}$ & $\begin{array}{l}\text { Mobile employees less } \\
\text { likely to developed } \\
\text { entrenched mental models, } \\
\text { but may succumb to } \\
\text { short-run decision making }\end{array}$ \\
\hline & & $\begin{array}{l}\text { Premium placed on } \\
\text { "owning" knowledge } \\
\text { workers }\end{array}$ & & & & \\
\hline
\end{tabular}


creasing imitation and low entry barriers, how will firms develop and then protect sources of competitive advantage within manufacturing? What potential sources of advantage will they choose to protect? As described, it is likely that technology and structural elements will not provide a source of advantage. However, the research theories that were discussed earlier suggest potentially contradictory strategic postures. The need to develop and protect difficult-to-imitate knowledge and routines, from the resource-based view, will work against the desire to gain access to an efficient market of manufacturers, consistent with transaction cost theory. How will firms weigh these contradictory priorities?

Cognitive and institutional theories may shed light on why firms will likely differ in their responses to this concern. Cognitive theory suggests that cognitive schema or mental models will play a significant role in how managers interpret these various environmental trends. For example, will managers who see manufacturing primarily as a collection of technologies be more likely to outsource manufacturing processes? Will managers who value manufacturing as a repository of complex routines, accumulated knowledge, and a source of causal ambiguity, be more likely to preserve and protect their production cores? If so, what are the predictors (education, background, experience) of those different strategic postures? Research into the links between competitive advantage in manufacturing and the background, education, and beliefs of manufacturing management will be a fruitful avenue for research in the future.

\subsection{Dissipating or accumulating knowledge}

Throughout this article, we have noted the arguments that firm-specific knowledge and complex routines are more likely to provide manufacturing-based competitive advantages in the future than technologies. However, in our discussion of inter-organizational integration we have highlighted concerns about knowledge spillovers, forces that encourage isomorphism, and the potential for erosion of firm-specific knowledge. These concerns provoke interesting research questions. With more extensive use of supply chain management practices and a more mobile workforce, how will firms prevent the dissipation of firm-specific knowledge about unique processes and routines, cost structures, quality practices, proprietary arrangements, and future plans? How will manufacturing firms balance institutional pressures for homogeneity with the organizational need to maintain a proprietary difference?

In counterpoint, however, there may be opportunities to accumulate knowledge across the networks of constituents, in unique and proprietary ways. For example, through effective management of partnering relationships, a manufacturing firm might be able to learn from suppliers, customers, or subcontractors. Application of absorptive capacity concepts (Cohen and Levinthal, 1990; Leonard, 1995), which are generally applied to technology transfer issues across technology alliances, has potential for directing research inquiry into the vertical knowledge accumulation that is possible through supply chain management practices.

\subsection{Manufacturing management}

Several research issues pertaining to the manufacturing workforce and manufacturing management team surfaced in our interpretation of trends. In what ways will mobility of knowledge workers influence manufacturing? Will mobility serve as a force for further isomorphism, or will it work to break-up rigid mental models about "the way things are done around here"? What background, education, and values best equip individuals to manage across cultures in an environment of rapid technology change? What actions will firms take to reduce their vulnerability to potential scarcities in skilled/knowledge workers?

These questions about manufacturing scope, advantage, integration, and management are just a sampling of the kinds of issues that will continue to surface in the next decade. They represent rich opportunities to explore application of multiple theoretical perspectives to conceptual and empirical studies.

\section{References}

Abernathy, W.J., Townsend, P.L., 1975. Technology, productivity, and process change. Technological Forecasting and Social Change 7, 379-396.

Abernathy, W.J., Utterback, J.M., 1978. Patterns of industrial innovation. Technology Review 80, 40-47. 
Amundson, S.D., 1998. Relationships between theory-driven empirical research in operations management and other disciplines. Journal of Operations Management 16, 341-360.

Auster, E.R., 1994. Macro and strategic perspectives on interorganizational linkages: a comparative analysis and review with suggestions for reorientation. In: Shrivastava, P., Huff, A., Dutton, J. (Eds.), Advances in Strategic Management, Vol. 10. JAI Press, Greenwich, CT, pp. 3-40.

Barney, J., 1991. Firm resources and sustained competitive advantage. Journal of Management 19, 99-120.

Baum, J.A.C., 1996. Organizations, technology and structuring. In: Clegg, S.R., Hardy, W.R., Nord, W.R. (Eds.), Handbook of Organization Studies. Sage, London.

Carlsson, B., 1989. Flexibility and the theory of the firm. International Journal of Industrial Organization 7, 179-203.

Coates, J.F., 1999. Twenty-first century work issues: a look back. Employment Relations Today 26, 1-9.

Cohen, W., Levinthal, D., 1990. Absorptive capacity: a new perspective on learning and innovation. Administrative Science Quarterly 35, 128-152.

Cohen, M.A., Apte, U.M., 1997. Manufacturing Automation. Irwin, Chicago.

Cowton, C.J., Vail, R.L., 1994. Making sense of just-in-time production: a resource-based perspective. OMEGA 22, 427441

Cyert, R.M., March, J.H., 1963. A Behavioral Theory of the Firm. Prentice-Hall, Englewood Cliffs, NJ.

Daft, R.L., 1989. Organization Theory and Design. West Publishing, St. Paul, MN.

Dess, G., Beard, D., 1984. Dimensions of organizational task environments. Administrative Science Quarterly 29, 52-73.

DiMaggio, P.J., Powell, W., 1983. The iron cage revisited: institutional isomorphism and collective rationality in organizational fields. American Sociological Review 48, 147160.

Gerwin, D., 1981. Relationships between structure and technology. In: Nystrom, P.C., Starbuck, W.H. (Eds.), Handbook of Organizational Design, 2nd Edition. Oxford University Press, New York.

Gibbs, B., 1994. The effects of environment and technology on managerial roles. Journal of Management 20, 581-604.

Grant, R.M., 1991. The resource-based theory of competitive advantage: implications for strategy formulation. California Management Review 33, 114-135.

Handfield, R., 1993. A resource dependence perspective of just-in-time purchasing. Journal of Operations Management 11, 289-311.

Hauptman, O., Hirji, K., 1999. Managing integration and coordination in cross-functional teams: an international study of concurrent engineering product development. R\&D Management 29, 179-191.

Haveman, H.A., 1993. Follow the leader: mimetic isomorphism and entry into new markets. Administrative Science Quarterly 38, 593-627.

Hayes, R.H., Wheelwright, S.C., 1979a. Link manufacturing and product life cycles. Harvard Business Review 57 (Jan/Feb), 131-141.
Hayes, R.H., Wheelwright, S.C., 1979b. The dynamics of process-product life cycles. Harvard Business Review 57 (Mar/Apr), 23-32.

Hayes, R.H., Wheelwright, S.C., 1984. Restoring Our Competitive Edge. Wiley, New York.

Hughes, J.J., 1997. Views of the future. In: Wolkoff, R.L. (Ed.), Next-Generation Manufacturing: A Framework for Action. The Agility Forum, Bethlehem, PA.

John, G., Weitz, B.A., 1988. Forward integration into distribution: an empirical test of transaction cost analysis. Journal of Law, Economics, and Organization 4, 337-355.

Kiesler, S., Sproull, L., 1982. Managerial responses to changing environments: perspectives on problem sensing from social cognition. Administrative Science Quarterly 27, 548-570.

Kim, Y., Lee, J., 1993. Manufacturing strategy and production systems: an integrated framework. Journal of Operations Management 11, 3-15.

Klein, S., Frazier, G.L., Roth, V.J., 1990. A transaction cost analysis model of channel integration in international markets. Journal of Marketing Research 27, 196-208.

Kotha, S., Orne, D., 1989. Generic manufacturing strategies: a conceptual synthesis. Strategic Management Journal 10, 211231.

LaHowchic, N.J., 1997. How Becton Dickinson built a supply chain business. Supply Chain Management Review 1, 52-59.

Lawrence, P.R., Lorsch, J.W., 1967. Organizations and Environments. Harvard University Graduate School of Business Administration, Boston.

Leonard, D., 1995. Wellsprings of Knowledge: Building and Sustaining the Sources of Innovation. Harvard Business School Press, Boston.

Leonard-Barton, D., 1992. Core capabilities and core rigidities: a paradox in managing new product development. Strategic Management Journal 13 (Summer Special Issue), 111-125.

Mabert, V.A., Venkatraman, M.A., 1998. Special research focus on supply chain linkages: challenges for design and management in the 21st century. Decision Sciences 29, 537-552.

Mahoney, J.T., Pandian, J.R., 1992. The resource-based view within the conversation of strategic management. Strategic Management Journal 13, 363-380.

McDougal, P.P., Deane, R.H., D’Souza, D.E., 1992. Manufacturing strategy and business origin in the computer and communications equipment industries. Production and Operations Management 1, 53-69.

Melnyk, S.A., Handfield, R.B., 1998. May you live in interesting times ... the emergence of theory-driven empirical research. Journal of Operations Management 16, 311-319.

Mills, D., 1984. Demand fluctuations and endogenous firm flexibility. Journal of Industrial Economics 33, 55-71.

Mills, D., Schumann, L., 1985. Industry structure with fluctuating demand. The American Economic Review 75, 758-767.

Mintzberg, H., Raisinghani, D., Theoret, A., 1976. The structure of 'unstructured' decision processes. Administrative Science Quarterly 21, 246-275.

Monteverde, K., Teece, D.J., 1982. Suppliers' switching costs and vertical integration in the automobile industry. Bell Journal of Economics 13 (Spring), 206-213. 
National Institute of Standards \& Technology, 1998. The nation's CEOs look to the future (press release), Foundation for the Malcolm Baldridge National Quality Award, Washington, DC. National Research Council, 1998. Visionary Manufacturing Challenges for 2020, National Academy Press, Washington, $\mathrm{DC}$

Nemetz, P.L., Fry, L.W., 1988. Flexible manufacturing organizations: implications for strategy formulation and organization design. Academy of Management Review 13, 627-638.

Oliver, C., 1997. Sustainable competitive advantage: combining institutional and resource-based views. Strategic Management Journal 18, 697-713.

Pearson, J.N., Feldman, H.D., Bracker, J.S., 1991. The impact of the product/production process interaction on the evolution of strategic response. Journal of Management Studies 28, 161-172.

Pfeffer, J., Salancik, G.R., 1978. The External Control of Organizations. Harper and Row, New York.

Pisano, G.P., 1990. The R\&D boundaries of the firm: an empirical analysis. Administrative Science Quarterly 35, 153-176.

Porac, J.F., Thomas, H., 1990. Taxonomic mental models in competitor definition. Academy of Management Review 15, 224-240.

Porter, M., 1980. Competitive Strategy: Techniques for Analyzing Industries and Competitors. Free Press, New York.

Porter, M., 1981. The contributions of industrial organization to strategic management. Academy of Management Review 6, 609-620.

Powell, T.C., Dent-Micallef, A., 1997. Information technology as competitive advantage: the role of human, business, and technology resources. Strategic Management Journal 18, 375405.

Powell, W.W., 1991. Expanding the scope of institutional analysis. In: Powell, W.W., Dimaggio, P.J. (Eds.), The New Institutionalization in Organizational Analysis. University of Chicago Press, Chicago, pp. 183-203.

Quick, R., 1999. Retail, like war, is hell at The Limited. The Wall Street Journal 21 April, B1.

Robertson, T.S., Gatignon, H., 1998. Technology development mode: a transaction cost conceptualization. Strategic Management Journal 19, 515-531.

Rumelt, R.P., 1984. Toward a strategic theory of the firm. In: Lamb, R. (Ed.), Competitive Strategic Management. Prentice-Hall, Englewood Cliffs, NJ, pp. 556-570.

Schroeder, D.M., Congden, S.W., Gopinath, C., 1995. Linking competitive strategy and manufacturing process technology. Journal of Management Studies 32, 163-189.

Schwenk, C.R., 1984. Cognitive simplification processes in strategic decision-making. Strategic Management Journal 5, $111-128$.

Simchi-Levi, D., Kaminsky, P., Simchi-Levi, E., 2000. Designing and Managing the Supply Chain. Irwin, Chicago.

Skinner, W., 1969. Manufacturing — the missing link in corporate strategy. Harvard Business Review 47 (May/June), 136-144.

Skinner, W., 1974. The focused factory. Harvard Business Review 52 (Nov/Dec), 113-121.
St. John, C.H., Harrison, J.S., 1999. Manufacturing-based relatedness, synergy, and coordination. Strategic Management Journal 20, 129-141.

St. John, C.H., Young, S.T., 1992. An exploratory study of patterns of priorities and trade-offs among operations managers. Production and Operations Management 1, 133-150.

Spender, J.C., 1996. Making knowledge the basis of a dynamic theory of the firm. Strategic Management Journal 17 (Winter Special Issue), 45-62.

Sulon, B., 1999. Pennsylvania-based Hershey Foods' distribution problems to continue. Knight-Ridder/Tribune Business News, 9 November.

Swamidass, P.M., Newell, W.T., 1987. Manufacturing strategy, environmental uncertainty and performance: a path-analytic model. Management Science 33, 509-524.

Sweeney, M.T., 1991. Towards a unified theory of strategic manufacturing management. International Journal of Operations and Production Management 11, 6-22.

Teece, D.J., Pisano, G., Shuen, A., 1997. Dynamic capabilities and strategic management. Strategic Management Journal 18, 509-534.

Thompson, J.D., 1967. Organizations in Action. McGraw-Hill, New York.

Tversky, A., Kahneman, D., 1986. Rational choice and the framing of decisions. Journal of Business 59, s251-s278.

Tyler, B.B., Steensma, H.K., 1998. The effects of executives' experiences and perceptions on their assessments of potential technological alliances. Strategic Management Journal 19, 939-965.

Ulrich, D., Barney, J.B., 1984. Perspectives in organizations: resource dependence, efficiency, and population. Academy of Management Review 9, 471-481.

Van Dierdonck, R., Miller, J.G., 1980. Designing production planning and control systems. Journal of Operations Management 1, 37-46.

Vickery, S., Dröge, C., Markland, R., 1993. Production competence and business strategy: do they affect business performance? Decision Sciences 24, 435-455.

Walsh, J.P., 1985. Managerial and organizational cognition: notes from a trip down memory lane. Organization Science 6, 280321.

Ward, P.T., Leong, G.K., Boyer, K.K., 1994. Manufacturing proactiveness and performance. Decision Sciences 25, 337-358.

Ward, P., Duray, R., Leong, G.K., Sum, C., 1995. Business environment, operations strategy and performance: an empirical study of Singapore manufacturers. Journal of Operations Management 13, 99-116.

Williams, F.P., D’Souza, D.E., Rosenfeldt, M.E., Kassaee, M., 1995. Manufacturing strategy, business strategy and firm performance in a mature industry. Journal of Operations Management 13, 19-33.

Williamson, O.E., 1975. Markets and Hierarchies: Analysis and Antitrust Implications. Free Press, New York.

Woodward, J., 1958. Management and Technology. H.M.S.O., London.

Woolsey, J.P., 1997. The 'revolution' grows: Boeing rolls out the 737-700. Air Transport World 33, 51-56. 